\title{
Dead voices and lost sounds: an imagined sonic history
}

\author{
Adrienne Kapstein \\ Pace University | USA
}

\begin{abstract}
A project description of a sound art installation and interactive performance presented as part of the Up Close Festival in New York City in the winter of $2019 / 2020$. The article is authored by the creator and director of the piece, Adrienne Kapstein. Created for an all-age audience, the piece was a unique, relational and socially engaged experience that merged sound art, live performance, illusion, technology, and audience participation. Designed to be completed in partnership with members of the community it sought to serve, the piece invited participation from every audience member through multiple and varied means of engagement.
\end{abstract}

Keywords: sound art, installation, performance, participation, theater for all ages, theater, history
Resumo: Uma descrição do projeto de instalação de arte sonora e performance interativa apresentada durante o Up Close Festival, na cidade de Nova York, no inverno de 2019/2020. O artigo é de autoria da criadora e diretora da peça, Adrienne Kapstein. Criada para um público de todas as idades, a peça foi uma experiência única, relacional e socialmente envolvida, que combinou arte sonora, performance ao vivo, ilusão, tecnologia e participação do público. Projetada para ser concluída em parceria com membros da comunidade à qual buscava servir, a peça convidou todos os membros do público a participar através de múltiplas e variadas formas de engajamento.

Keywords: arte sonora, instalação, performance, participação, teatro para todas as idades, teatro, história 
"Dead voices, lost sounds, forgotten noises, vibrations lockstepping into the abyss, and now too distant to be recaptured!" Future Eve by Auguste Villiers de l'Isle-Adam

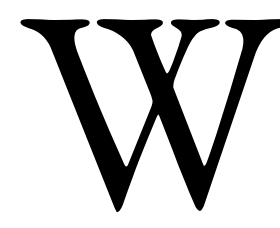

hat if the dead voices, lost sounds, and forgotten noises of the past could be heard? What if sound waves did not dissipate but rather resonated for all time? What if sound seeped into the material world around us and we could excavate and resurrect these sonic artifacts? What would this sonic history tell us? These were the playful premises that inspired The Society of Historic Sonic Happening or SHSH; part sound art installation; part immersive and interactive theatrical performance created for an audience of all ages created and directed by, Adrienne Kapstein, and sound designer, Bhurin Sead, and presented in the Up Close Festival at the New Ohio Theater in New York City in the winter of 2019/2020.

SHSH was a unique project with artistic, communal, and social impact in its relational performance practice (WALMSLEY, 2013, p. 108); its site specific, immersive, and multisensory approach; integrated audience participation (O’TOOLE, 1976, p. 88), and intergenerational scope. SHSH also proposed a deliberately decentered and radically inclusive perspective on the past by posing the premise that history is made up not only of monumental and memorable moments but also unseen and forgotten stories - human and non-human events included. By honing in on a simultaneously micro and macro historic scale, SHSH asked the audience to reconsider history and their place within it - as an infinite tapestry of tiny, interconnected moments.

Deeply influenced by the notion of "heightened listening" as pioneered by composer and sound ecologist Hildegard Westerkamp (WESTERKAMP, ISEA, 2015), SHSH used the act of listening as a thematic entry point into the piece. Like Westerkamp's vision of a sustained and ongoing listening practice which amplifies and reveals "that which is ignored and normally avoided" and in which the ultimate goal is to be able to "return with changed perspective into the places of daily life" (WESTERKAMP), the creators of SHSH hoped to shift the perspective of the audience to awaken and ignite their interest in their immediate surroundings as well as to the invisible palimpsest of pasts surrounding them. Like a sonic rendering of a Muir Web - a dense diagram of thousands of intersecting lines as a visualization of habitat relationships (The Welikia 
Project, WCS 2008 - 2017) named after the famous naturalist, John Muir - SHSH aspired to convey the idea that every event and every being is connected, interdependent, and necessary. As Muir once wrote, "When we try to pick out anything by itself we find that it is bound fast by a thousand invisible cords that cannot be broken, to everything in the universe." [The Welikia Project)

FIGURE 1 - A Muir Web showing "all the habitat relationships for all the species on Mannahatta" (Welikia Project, WCS, 2008 - 2017)

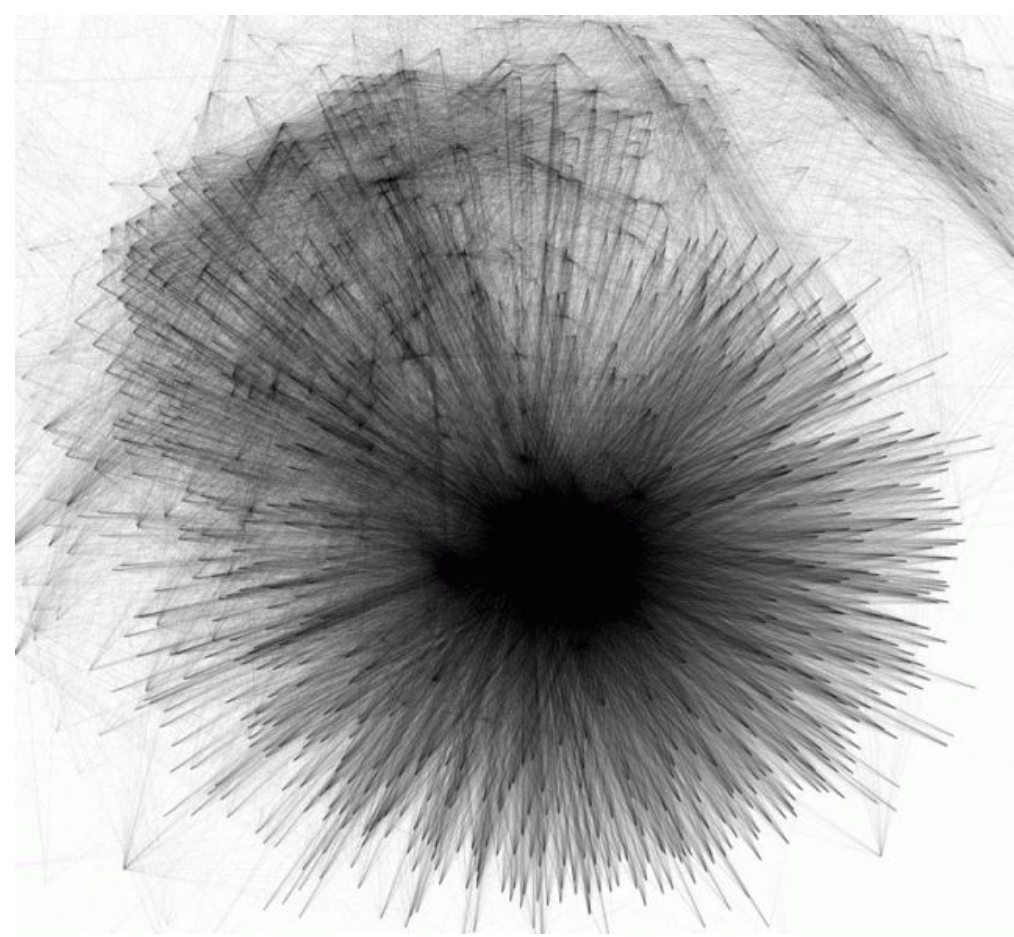

Source: Visualization by Chris Harrison of Carnegie-Mellon University oWCS https://welikia.org/science/recreating-mannahatta/

The driving force behind the Up Close Festival, and the works contained within it, was to build community and conviviality through the connection and interaction with the space, the neighborhood, the city of New York: past, present, and future. Artists were commissioned to create short-form works that were immersive, site specific, and site responsive to the location. The theatrical framing of the festival as a whole invited audiences to re-contextualize their relationship to the site - the building and the land on which it stands - and reimagine The New Ohio Theater, also known as The Archive Building, as a living archive in which the collective task of the audience and performers alike was to joyfully excavate - as well as to reimagine and construct - the neighborhood's history and its journey through time. (MUSANTE, 2019, p. 1). From a theoretical 
lens, SHSH is situated within Bourriaud's concept of relational aesthetics (BOURRIAUD, 2002, p. 112) which has been defined as artistic endeavour based on human interaction in social spaces (WALMSLEY, 2013, p. 110) and the idea that participatory works of art can foster a "social bond through the collective creation of meaning." (BISHOP, 2006, p. 12) Audiences were given space within the dramaturgical structure of the piece to write imagined and collectively constructed histories which were added to the sound installation as a living documentation of the communal contribution.

PICTURE 1 - Audience examining sound jars in the SHSH installation, Up Close Festival, December 30, 2019.

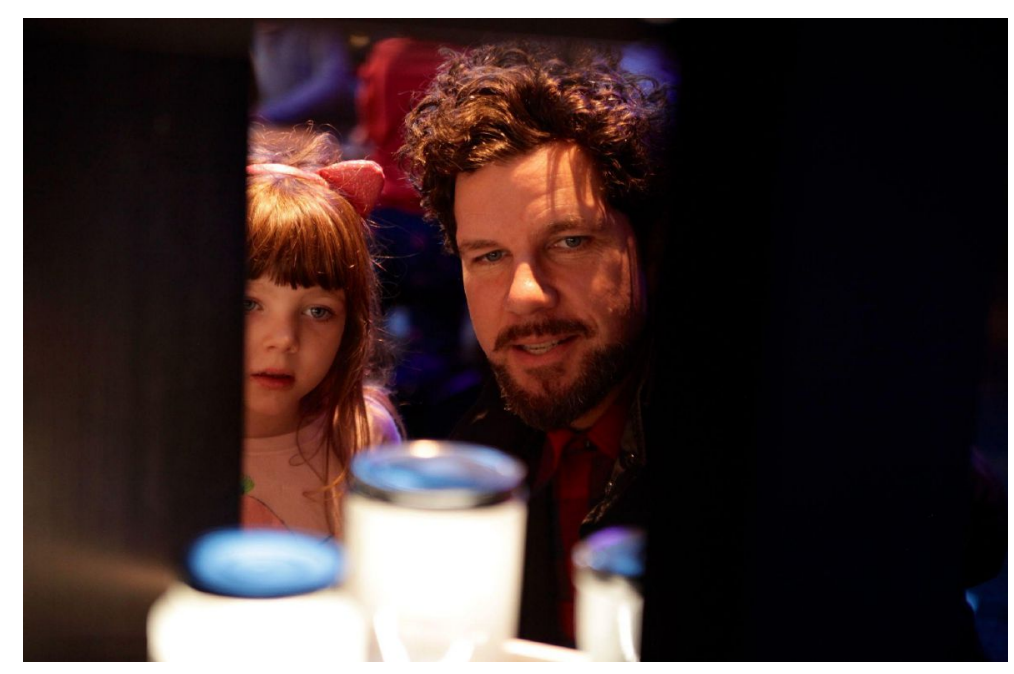

Photo Credit: Nicholas Morgulis

PICTURE 2 - Child engrossed in listening to a sonic sample in an archival jar, Up Close Festival, January 2, 2020.

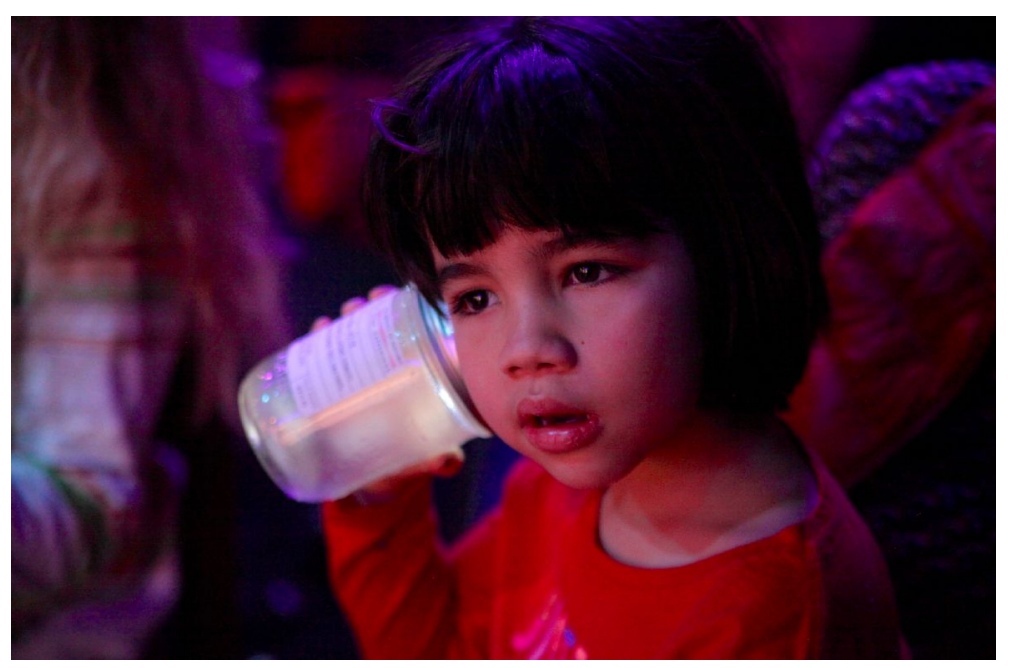

Photo Credit: Nicholas Morgulis 


\section{Project Description}

The Society of Historic Sonic Happenings was inspired by a potpourri of pseudoscientific theories woven together to create an elaborate theatrical framing device that ignited the audience's imagination and laid the ground for participation. These included the 19th century ideas of psychometry and place memory - the beliefs that objects retain traces of experiences from the past and that certain physical locations can absorb moments and events only to leak them later in the form of apparitions and ghosts. (HILL, 2017) These were combined with the apocryphal anecdote that Guglielmo Marconi, the father of modern radio, had a late-in-life epiphany in which he became convinced that sound never dies but instead becomes too quiet for human ears to detect. (DIMEO, 2009) It is said that he envisioned a "device that would let him hear lost sounds, let him tap into these eternal frequencies. He would tell people that if he got it right, he could hear Jesus of Nazareth giving the Sermon on the Mount.. ${ }^{1}$ Added onto these fictions was the imagined layer that SHSH was an experimental wing of Bell Laboratories - the original location of which is only a few blocks from the theater venue. Once known as "The Idea Factory” (GERTNER, 2012), Bell Labs is credited with the development of early synchronous-sound motion picture as well as the development of radio astronomy, the transistor radio, and the laser, among others. It was a simple stretch of the imagination to envision this same laboratory as housing SHSH's sound scientists.

A final fictional conceit was that children make the best 'sound hunters' able to pick up on 'sonic artifacts' at a broader frequency range than adults. This premise endowed the child audience with authority, making them the "heroes" of the piece (SHMIDT-CHAPMAN, 2015) essential for the success of the fictional mission. It also playfully elicited participation by enabling them to be in role' without the pressure of acting and allowing themselves to still be themselves (O'TOOLE, 1976, p. 109).

As a sound art installation, SHSH existed as an archive of hundreds of glowing glass jars each emitting small and seemingly insignificant sounds from the past. The sonic samples were an unabashed mix of fact and fiction with the vast majority being a mix of the two. Equipped with small battery powered audio modules that fit underneath the lids and hidden from view, audiences

\footnotetext{
${ }^{1}$ Ibidem.
} 
were encouraged to interact with this sonic collection and to touch, listen to, and examine the jars with curiosity and care. Each of these sound jars were identified with a field label meticulously describing the sonic specimen, a phonetic transcription of the sound, the coordinates of where it was found, and the date of when the event that produced the sound originally occurred. Taken together, these individual sounds created an accumulative imagined sonic portrait of a place over time.

Some examples of these sonic specimens contained in the archive included: the ping of a button from a Redcoat's coat falling onto frozen mud during the Battle of Golden Hill in 1770 CE, located at $40.7362^{\circ} \mathrm{N} 74.0136^{\circ} \mathrm{W}$, the current location between Bethune Street and West 12 th Street in the West Village, 9 blocks from the New Ohio Theater; the sound of children playing in water from a fire hydrant on August 22, 1928 on the sidewalk outside of Engine Company 18 on West 10th Street, six blocks from the theater ${ }^{2}$; the crunch of a dried tobacco leaf under a foot during the Lenape fall harvest, September 18th 1447, location: Sapokanikan, the indigineous Lenape name for what is now known as Greenwich Village; the keebo and buzz of wings of a raucous flock of passenger pigeons flying over Waverly Place and West 10th street, May 19th, 1232 CE; mixed human noise of sixteen families in four apartments at No. 31-33, Carmine Street, December 1st, 1873, CE; the ouch of Vinnie Dapolito getting his ears cleaned at the Carmine Street Bathhouse, August 14th, $1909 \mathrm{CE}$; the weeeoooowwww of Jimi Hendrix riffing on an electric guitar at the Electric Lady Studio, 52 West 8th Street, August 24, 1970 CE; the oob abh of a crowd jostling to see first squirrel in tree in Washington Square Park, February 3, 1856 CE; shrieks carried across Hudson River from mothers and children attacked during the night by Dutch soldiers, February 25, Pavonia, NJ, $1643 \mathrm{CE}$; the squelch of an oyster sinking into mud in the Hudson River near current location of Leroy Street, circa 6500 BCE; and the squeak squeak of a hungry pigeon squab on 10th floor window ledge of the Archive Building, April 14, 2019. ${ }^{3}$

\footnotetext{
${ }^{2}$ This sound sample was one of the few taken from an actual recording of an historic event itself. Originally located at The NYC Department of Records Municipal Archives, the creative team of SHSH came across it on the digital history site, The Roaring Twenties, which is a collaboration between Emily Thompson of Princeton University and Scott Mahoy of the University of Southern California and compiles audio files and written noise complaints from 1920s New York City.

3 A recording of further examples of sound jars included in the sonic archive is available at: http://vortex.unespar.edu.br/kapstein_v9_n2a.mov
} 
PICTURE 3 - Examples of sound jars included in the sonic archive sound installation

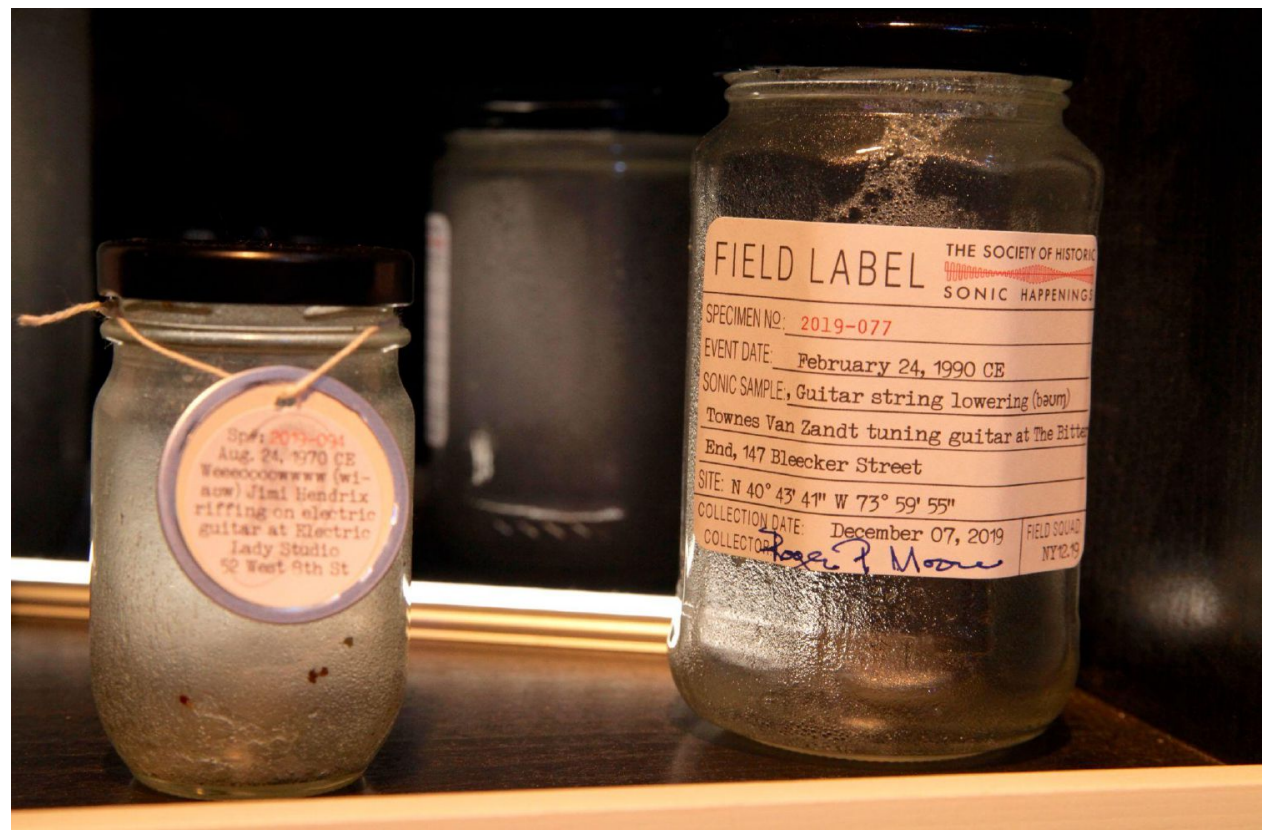

Photo Credit: Nick Morgulis

During the performance element of the piece, audiences were guided by a team of actors in role as sound scientists. Costumed in lab coats and equipped with 'sound hunting technology', audiences were led from the sound installation into a participatory excavation to locate, preserve, and identify undiscovered sonic specimens within the site of the theater venue. With the use of wearable, hidden sound devices that amplified sound through transducers onto surfaces, the performers created the audio illusion that sounds were embedded in the physical space and could be listening to by a 'listening probe' - a tin can playfully evoking the familiar string telephone experiment of childhood - and transferred into a 'preservation vessels' - aka the humble and quotidien glass jar and evocative of eavesdropping through walls. Audiences were given the task of working together to listen to found sounds, identify and capture them into the jars, and transcribe their findings onto field labels which were then placed onto the jars and added to the sonic archive (sound installation). In doing so, they became complicit in the creation and curation of a collective imagined history.

Using O’Toole's distinction that there are three types of participation possible in a theatrical experience: Extrinsic, where the element of participation is separated from the theatricality; Peripheral, in which the audience is invited to contribute by the fundamental structure of the play 
is unaffected, or Integral, where the structure of the piece and the audience's relative position to it, and therefore the total experience is altered (O'TOOLE, 1976, p. 88), SHSH harnessed audience participation in a profoundly integrated manner. Audience involvement shaped each performance by permanently altering the piece as each discovered sound was added to the archive collection and growing the sonic history of the place in real time over the course of the run. Each performance and each audiences' contributions forever altered the installation for future audiences to encounter.

The culmination of the piece brought the audience back into the present by capturing the collective sound of the audience itself into a jar and archiving it as an historic event. As the world starts to reemerge from the lockdowns of the COVID-19 pandemic, this moment is particularly poignant in retrospect. Please reference the appendices to hear the recorded sound of a sold-out house of children and adults joyfully sharing space as they shouted out their names and names of someone they love in the final performance of the run. ${ }^{4}$

FIGURE 2 - The label of the final jar that captured the sounds and voices of the audience.

\begin{tabular}{|c|c|}
\hline \multicolumn{2}{|c|}{ 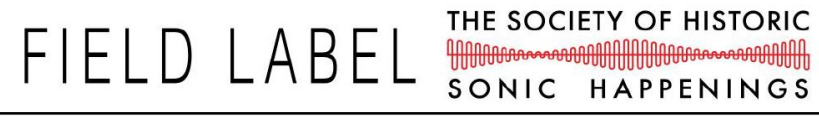 } \\
\hline \multicolumn{2}{|l|}{ SPECIMEN NNo: $2020-212$} \\
\hline \multicolumn{2}{|l|}{ EVENT DATE: January 4, $2020 \mathrm{CE}$} \\
\hline \multirow{2}{*}{\multicolumn{2}{|c|}{$\begin{array}{l}\text { SONIC SAMPLE: Woohoo Weee! Hello! (woohoo wi: } \\
\text { 'IOU) Honorary members of the Society of }\end{array}$}} \\
\hline & \\
\hline \multicolumn{2}{|c|}{ Historic Sonic Happenings } \\
\hline \multicolumn{2}{|c|}{ SITE: Archive Building, Greenwich Village, NY } \\
\hline $\begin{array}{l}\text { COLLECTION DATE: January } 4,2020 \\
\text { COLLECTOR: }\end{array}$ & $\begin{array}{l}\text { FIELD SQUAD: } \\
\text { NY12.19 }\end{array}$ \\
\hline
\end{tabular}

As with all the works in the Up Close Festival, SHSH was a site specific and immersive, hands-on experience in which the audience were free to move within the theater space and the performances occurred in and around, and indeed up close, to them. For a performance to be site specific, "its content, form, and structure must be generated from its actual place of performance" (BALL, 2018, p. 3) and in order for a work to be authentically specific and responsive to the site on

\footnotetext{
${ }^{4}$ The recording of the Final Jar is avalilabe at: http://vortex.unespar.edu.br/kapstein_v9_n2b.mov
} 
which it occurs, the site and its past must be embedded in "the dramaturgy of the space within the production."(ECKERT, 2021) As Mike Pearson and Michael Shanks state in their frequently referenced definition of site specific work:

\footnotetext{
Performance recontextualizes such sites: it is the latest occupation of a location at which other occupations - their material traces and histories — are still apparent: site is not just an interesting, and disinterested, backdrop... Interpenetrating narratives jostle to create meanings. The multiple meanings and readings of performance and site intermingle, amending and compromising one another. (PEARSON; SHANKS, 2001, p. 23)
}

Embedded in these definitions of site specific work however, is the assumption that the location(s) for the production is probably somewhere unconventional and somewhere outside of the purposebuilt theater. (BALL, 2018, p. 3) However, in the instance of SHSH and the Up Close Festival, the theater was both the venue and the locale of the site-specific performance. SHSH used The New Ohio Theater itself as the site to investigate, interrogate, and reconsider by engaging with the basement theater's previous incarnations as a 19th century appraiser's warehouse; a United States Federal warehouse from the end of the 19th and into the early 20th century; a National Archives Record Center in the first half of the 20th century; luxury lofts in the 1980s, and now one of the West Village's most prestigious rental residences. In addition, the creative team of SHSH, were also interested in expanding the site - and the dialogue between place and performance - beyond the building itself to the neighborhood on which it stands, Greenwich Village, one of the oldest in Manhattan, and the land itself, originally Manahatta, home of the indigenous Lenape people. In an interview about the festival, Take a Closer Look, Inside the Up Close Festival of Immersive Theatre for Young Audiences, Peter Musante, producer and curator of Up Close, stated that in embracing this locale the creators of the work - and therefore the audience - take on “... the responsibility of honoring indigenous communities and other voices whose histories are often excluded from collective memory.” (SHMIDT-CHAPMAN, 2019).

Machon defines immersive theater as ".. a performance form emphasizing the importance of space and design; curating tangible, sensual environments; and focusing on personal, individual audience experience.” (MACHON, 2013, p. 66). Immersive work blurs the boundaries between performer and spectator and situates the audience within the work creating possibilities for audience performer interaction, engagement, participation, and affect. Theater for Young 
Audiences has a long history of immersive and participatory performance experiences as there is nothing more avant-garde than a child's imagination (KAPSTEIN; GOLDSTEIN, 2019, p. 1) and many artists making work for children harness the innate imaginative capabilities of childhood to free themselves from linear dramaturgies and representational theatrical models with traditional spectator actor relationships. As Sarah Morgulis, co-producer of the festival and Director of Education at New York City Children's Theater states in the aforementioned interview about Up Close: "Immersive theatre is the best way to engage young people because it gives them something that they lack in so many other areas of the rest of their lives-agency! By creating short-form theatre, every interaction is immediate and important. The young audiences are engaging in the storytelling moment to moment.” (SHMIDT-CHAPMAN, 2019)

In addition to the immediacy provided by its immersive nature, the multisensory and kinetic nature of the piece was an essential part of the creative vision and the creative team's interest in intergenerational accessibility and engagement. It was structured to allow for multiple modes of entry - verbal, textual, auditory, visual, and haptic - regardless of age. For example, the piece could be accessed through an intellectual lens - reading the detailed labels describing the sonic artifacts captured within each jar, or enjoyed through a primarily physical encounter with the sound jars as they emitted noises contained within them. Audiences could follow the narrative framework of the piece and opt in — or out — as the performers invited audiences to physically explore the space and hunt for hidden sounds. One of the most universally impactful moments was when the sounds were 'discovered' and 'captured'. With the use of technology and theatrical sleight of hand, audience members — old and young — were disarmed and delighted as they heard sounds emanate from walls, saw them scooped them into a jar, and then heard the sound once again as it was 'captured' inside the preservation vessel.

Overall, the Society of Historic Sonic Happenings installation, performance, and participatory experience engaged audiences of all ages and abilities in a playfilled, socially engaged, and hyperlocal experience that was deeply connected to the shared public space. With sound objects that could be handled, listened to, read, ordered and categorized, it invited a sensuous, intellectual, and imaginative engagement with the imagined sounds of past and by association, a re-connection and re-imagining of the history and physical locale of the venue in which the piece was set. SHSH 
proposed a vision in which the minutiae of the past is magnified and we are made to realize that we are intimately connected to everyone and everything; we are connected to who and what was here before us, and we are also connected to those gathered together in the space during the performance itself. The interactive element of SHSH fostered small, ephemeral communities that lasted during the duration of the piece as groups of strangers were invited to search for sounds and write a collective imagined history together. These moments of social participation were then preserved and recognized as history by being added to the archive as a living record of the collective contribution to the work.

\section{REFERENCES}

BALL, Joyelle Klaer. Crises of Site: Non-specificity in the Theater. Dissertation for PhD in Theater Studies. University of California, Santa Barbara. ProQuest Dissertations Publishing, 2018.

BISHOP, Claire. Participation. London: Whitechapel Gallery; Cambridge, Mass.: The MIT Press, 2006.

BOURRIAUD, Nicolas. Relational Aesthetics. Translated by Simon Pleasance and Fronza Woods. Les Presse Du Réel, 2002.

DIMEO, Nate, These Words Forever. Podcast The Memory Palace, Episode 12. Available at: https://thememorypalace.us/2009/06/episode-12-these-words-forever. Accessed: 01 Dec. 2021. Radiotopia, 2009.

ECKERT, Stephen. What is Immersive Theatre? Contemporary Performance, November 9, 2021. Available at: https://contemporaryperformance.com/2021/11/09/immersive-theater/. Accessed: 01 Dec. 2021.

GERTNER, Jon. The Idea Factory: Bell Labs and the Great Age of American Innovation. Penguin Books, 2012.

HILL, Sharon. Spooky Rocks. Skeptical Inquirer, Volume 27:3, January, 2017. Available at: https://skepticalinquirer.org/newsletter/spooky-rocks/. Accessed: 01 Dec. 2021.

KAPSTEIN, Adrienne; GOLDSTEIN, Thalia. Developing wonder: Teaching theatre for the very young through collaboration with developmental psychology. Youth Theatre Journal, 16 April 2019.

MACHON, Josephine. Immersive Theaters: Intimacy and Immediacy in Contemporary Performance. Basingstoke: Palgrave Macmillan, 2013.

MUIR, John, referenced at https://welikia.org/, WCS, 2008-2017.

MUSANTE, Peter. Up Close Festival 2019 Maker's Guide for commissioned artists. December 
2018, with revisions September, 2019 (not published).

O’TOOLE, John. Theatre in Education, New objectives for theatre - new techniques in education. Kent: Hodder and Stoughton, 1976.

PEARSON, Mike, SHANKS, Michael. Theatre/Archaeology. Routledge, 2001.

SHMIDT-CHAPMAN, Jonathan, Artistic Director; Trusty Sidekick Theater Company (20112016). Press Release for Up and Away, BroadwayWorld JR, Sept. 29, 2015. Available at: Broadwayworld.com

SHMIDT-CHAPMAN, Jonathan. Take a Closer Look, Inside the Up Close Festival of Immersive Theatre for Young Audiences. TYA/USA, Nov. 17, 2019. Available at: https://www.tyausa.org/tyatoday/take-a-closer-look/. Accessed: 01 Dec. 2021.

VILLIERS DE I’ISLE-ADAM, Auguste. Future Eve. Tradition Classics, November 23, 2012.

WALMSLEY, Ben, Co-Creating theatre: authentic engagement or inter-legitimation? Cultural Trends, Vol. 22, No. 2, p. 108-118. DOI: $\underline{10.1080 / 09548963.2013 .783176}$

WESTERKAMP, Hildegard (interview). Ear Room by Mark Peter Wright. July 6, 2011. Available at: https://earroom.wordpress.com/2011/07/06/hildegard-westerkamp/. Accessed: 01 Dec. 2021.

WESTERKAMP, Hildegard. The Disruptive Nature of Listening. Keynote Address, at International Symposium on Electronic Art, Vancouver, B.C. Canada August 18, 2015. Available at: https://www.hildegardwesterkamp.ca/writings/writingsby/?post $\mathrm{id}=11 \&$ title=the-disruptivenature-of-listening\#: : text $=\mathrm{By} \% 20 \mathrm{its} \% 20 \mathrm{very} \% 20$ nature $\% 20$ listening,is\%20disruptive\%20in\%20its\%20nature. Accessed: 01 Dec. 2021.

\section{ABOUT THE AUTHOR}

Adrienne Kapstein is a collaborative theater-maker, director, and theater educator. She creates visually rich, physically adventurous new work and participatory performance experiences that exist across various mediums. Adrienne is interested in building community through the connection and interaction with public spaces and is passionate about bringing experimental work to audiences of all ages and sharing live art across generations. Her work has won multiple awards and has been presented in the U.S., Canada, Scotland, Ireland and Romania. Adrienne is an Associate Professor at Pace University and the head of the BA Acting/BA Directing International Performance Ensemble program. ORCID: https://orcid.org/0000-0003-0158-4733. E-mail: akapstein@pace.edu 